\title{
RACE DISCRIMINATION IN TONY KUSHNER'S MOVIE SCRIPT LINCOLN
}

\author{
Sri Astuti Rambe, Asnani \\ Faculty of Literature, Universitas Islam Sumatera Utara \\ Medan, Indonesia \\ e-mail: riarambee@gmail.com
}

Received: 2021-10-15

Accepted: 2021-11-21

\begin{abstract}
This research is concerned with the race discrimination in Tony Kushner's movie script Lincoln. A story of four months of struggle of Lincoln and the Republican party and its supporters to pass the 13th amendment which formally abolished slavery in the United States passing the Senate on April 8, 1864, and the House on January 31, 1865 and approved by President Abraham Lincoln on February 1, 1865. The analysis focuses on the types of race discrimination: the direct and the indirect of race discrimination and the negative impacts of race discrimination adopted from Liliweri. This research used descriptive qualitative research. The one adopted in the research is proposed by Khotari and Bogdan \& Taylor. The finding shows that the direct race discrimination is an act of limiting a job based on race. It comes from black soldiers. There is also a tendency to discriminate between groups and beliefs with human law itself. The negative impacts of race discrimination are slavery and civil war. Furthermore, race discrimination also causes heavy casualties between whites and blacks by taking over place the territories of the minority.
\end{abstract}

Keywords: direct race discrimination, indirect race discrimination, slavery, civil war.

\section{Introduction}

United States is inhabited by various racial groups in almost all sectors of life, but it is dominated by white citizens. They are the Caucasian race. White people oppresses African and American immigrants who come from the Nigger race. It is place of black people at the lowest position in the racial and ethnic strata based on the degree of dominance. Nigger races are also separated from white citizens in social facilities and are limited in their scope of movement in the political field. Race viewed from a biological point of view is human population that is divided into social classes according to heredity characteristics that distinguish one group or human group from another (Marger, 1994: 19). This phenomenon is situation that initiates the author

Lincoln is a 2012 American biographical historical drama movie directed by Tony Kushner's. This movie tells the story of four months of struggle of Lincoln and the Republican party and its supporters to pass the 13th amendment until his death. The 13th amendment, which formally abolished slavery in the United States, passed the Senate on April 8, 1864, and the House on January 31, 1865. On February 1, 1865, President Abraham Lincoln approved the Joint Resolution of Congress submitting the proposed amendment to the state legislatures. The necessary number of states ratified it 
by December 6, 1865. The 13th amendment to the United States Constitution provides that neither slavery nor involuntary servitude, except as a punishment for crime whereof the party shall have been duly convicted, shall exist within the United States, or any place subject to their jurisdiction.

In this research, the researchers analyze race discrimination in Tony Kushner's movie script Lincoln. It is very interested to be analyzed because discrimination is an oppression which has negative impact to the minority. Therefore, the researchers would like to know what the reason and the impact of discrimination reflected in movie. Hopefully, this analysis will give contribution to the readers of this research either practically or theoretically. Therefore, the readers of this research might avoid doing discrimination to other people individually or collectively.

\section{Literature Review}

Quillian (2006) states that discrimination is distinct from racial prejudice (attitudes), racial stereotypes (beliefs), and racism (ideologies) that may also be associated with racial disadvantage. Discrimination may be motivated by prejudice, stereotypes, or racism, but the definition of discrimination does not presume any unique underlying cause. Reskin (1998:32) states that differential treatment occurs when individuals are treated unequally because of their race. Disparate impact occurs when individuals are treated equally according to a given set of rules and procedures but when the latter are constructed in ways that favor members of one group over another. The second component of this definition broadens its scope to include decisions and processes that may not themselves have any explicit racial content but that have the consequence of producing or reinforcing racial disadvantage and beyond more conventional forms of individual discrimination, institutional processes such as these are important to consider in assessing how valued opportunities are structured by race.

What is meant by discrimination is any restriction, harassment or exclusion that is directly or indirectly based on human differences on the basis of religion, ethnicity, race, ethnicity, group, class, social status, economic status, gender, language, political beliefs, which results in the reduction, deviation or elimination of the recognition, implementation or use of human rights and basic freedoms in both individual and collective life in the political, economic, legal, social, cultural and other aspects of life. It is supported by Theodorson and Theodorson (1979: 258-259) stating that discrimination is an unfair treatment to the individual, group or community based on something. Customarily it has categorical, special attribute such as: race, ethnic, religious, and social class. It should be underlined that discrimination means unequal treatment of a group of people, which is essentially the same as a group of perpetrators of discrimination. The object of discrimination actually has some of the same capacities and services, which are universal. Whether discrimination is considered illegal, depends on the values held by the community concerned, or rank in society and the stratification of society based on the principle of discrimination. Fulthoni (2009) says that the types of discrimination that often occur are as follows:

a. Discrimination based on ethnicity, ethnicity, race and religion. Racial and Ethnic Discrimination is any form of distinction, exclusion, limitation, or election based on race and ethnicity, which results in revocation or reduction of recognition, acquisition, or implementation of human rights and basic freedoms in an equality in the civil, political, economic, social and cultural fields. 
b. Discrimination based on gender. Gender discrimination is a condition where there is gender inequality or inequality that makes both women and men victims. This usually happens because the community or a group has an understanding to defend or oppress community groups based on their gender due to misunderstanding of goals and objectives. In this discrimination there are usually differences of opinion based on the position and position of men and women. Women who incidentally are weaker than men in terms of strength, usually often receive pressure and discrimination in the form of oral and treatment.

c. Discrimination against people with disabilities. Discrimination against people with disabilities is based on their physical condition or disability. So far, society treats people with disabilities differently based on assumptions or prejudices that people with disabilities have conditions because they are considered unable to carry out activities like other people in general. From a medical point of view, disability is a biological (pathological) condition, which means that this condition is something that a person is born with (not caused by the environment). In this case people with disabilities are rated as sick and dependent on medical services. People with disabilities are seen from a moral point of view, people with disabilities are associated as people with sin and crime. This kind of discriminatory treatment can be seen clearly in the field of employment. Employers are mostly reluctant to accept a person with a disability as an employee. They assume that a person with a disability will not be able to do a job as effectively as other employees who are not disabled. So for job providers, employing people with disabilities is similar to providing opportunities for companies to lose because they have to provide several tools to make it easier for people with disabilities to carry out their activities.

d. Discrimination against people with HIV/AIDS. Stigma that often appears to people living with HIV/AIDS often leads to discrimination which can eventually lead to human rights violations against sufferers and their families. Some examples are hospital or prison staff who refuse to provide health services to people living with HIV and there are layoffs or refusal of employees and people who are assumed to have this disease.

e. Discrimination because of social caste. This form of discrimination because of social caste (in this case is social stratification) is a form of discrimination that is currently happening at many levels of society. Those who feel they have do not want to share with those in need due to a feeling of lack of equality between the two parties or more. This usually happens because of the perspective of most people who look down on the status of society between one group and another.

\subsection{Types of Race Discrimination} discrimination:

According to Liliweri (2018: 398) there are two main types of race

\section{Direct Race Discrimination}

Direct discrimination occurs when laws, regulations or policies clearly state certain characteristics, such as gender, race, and hinder equal opportunities. Direct discrimination happens when you are treated differently and worse than someone else for certain reasons. Direct race discrimination can be because of:
a) Age
b) Disability
c) Gender reassignment 
d) Marriage or civil partnership

e) Pregnancy and maternity

f) Race

g) Religion or belief

h) Sexual orientation.

\section{Indirect Race Dicrimination}

Indirect discrimination occurs when neutral regulations become discriminatory applied in the field. The examples of indirect discrimination include the following:

a) The distinction between the black race and the white race.

b) Different treatment is carried out by the government towards one area, where the government only focuses on the development of certain areas and does not look at other areas.

c) Choose to choose friends who are of the same religion as him and don't want to hang out with friends of different religions.

d) In the world of work, there are differences in the provision of wages or salaries to an employee. Even though the two employees are in the same position and class.

\subsection{Negative Impacts of Race Discrimination}

Race discrimination from a social perspective are isolated from the general public. In America, social discrimination has resulted in a profound divide between blacks and whites. Violence and intimidation are an integral part of the lives of black people in America. According to Feagin (1995), the negative impacts of race discrimination are:

\section{Slavery}

One of the negative impacts of racial discrimination in the movie script Lincoln is slavery. Black people made slaves to work for white people for low salary. They are forced to work tirelessly. White people's treatment of black slaves was inhuman.

Krout (1971: 128) states that slavery that occurs in the United States is a social institution where slaves are bound by a number of rules imposed on slaves and must be obeyed. Slavery practices show the existence of an exploitation of fellow human beings. Slaves are considered property that is fully controlled by their owners, so they are easy to trade. Its became increasingly widespread with the development of cotton and sugar cane in this region in the last decades of the 18th century.

Castells (2011) says that status as immigrants and low-wage recipients for hundreds of years made the black group as a slave. The white community felt that the black group was not part of their group, so that various struggles emerged in the name of the emancipation of the black group to fight against the discriminatory order in society. Simply put, to escape the existing stigma, black groups must develop their potential to be balanced with white groups. Interestingly, not all opportunities are given equally to black groups due to the existence of white privileges that apply socially, as if there are restrictions on black groups to develop their potential, especially in the economic field.

Shenton and Rodney (1975) state that black people find it difficult to develop their economic capabilities due to the giant pressures of the United States and Europe, as well as social class that puts black groups at a disadvantage. This is in line with the political economy analysis that the author has explained earlier as a form of the success 
of the United States and Europe in cornering the existence of Africa and black groups economically, socially, and politically.

\section{Civil War}

Civil war has a lasting impact. Although slavery was successfully abolished after the defeat of the South in America, discrimination of skin color still persisted until the middle of the 20th century. Soetopo (2010: 39) says that war has left a legacy of local hatred which has been sharpened by harsh reconstruction policies following the victory of the North.

This civil war caused an impact in all fields, especially the negative impacts to the labor which causes bloodshed and loss of property such as loss of houses, livestock and means of transportation.

According to Powel 2006), there are some negative impacts caused by civil war. They are:

(a) The collapse of the South's economy, this is due to the destruction of plantations due to the war that lasted for 4 years. When the war takes place, it is not uncommon to have damaged the nature around the battlefield. For example, in communities in South America, whose economy depends on nature, there is a big problem as money and federal bonds are no longer valuable.

(b) The war that lasts for 4 years has consumed manpower and caused bloodshed and lost property such as the loss of houses, livestock and transportation equipment. The death toll from the federal side is around 360,000, which is roughly the same as the victims of World War II.

(c) The separation of 11 states in the South at the outbreak of war. This is because the soft reconstruction carried out by Lincoln is opposed by congress on the grounds that if those who broke away must be punished severely.

(d) The emergence of a sense of hatred from the Southern United States towards Negroes who have equal status with white people.

\section{Research Method}

In conducting research, researchers need research design. Research design refers to the strategy to integrate the different components of research projects in cohesive and coherence way. Descriptive qualitative method is concerned with describing the characters of a particular individual or of a group situation (Khotari, 2005: 37). Sherman and Webb (1988) assume that qualitative research is concerned with meaning as they appear to achieved by persons in lived social situations. Meanwhile, Bogdan and Taylor (1975: 4) state that qualitative method refers to research procedures which produce descriptive data. The researchers use descriptive method to describe and interpret the objects in accordance with reality. The descriptive method is implemented because the data analysis is presented descriptively. The researchers use selected movie script Lincoln directed by Tony Kushner.

In a research, data collection is one important consideration. Data collection shows how the researchers collect the data that will be analyzed. There must be some procedures or steps taken by the writer to gather the data. The data of this research is collected through some steps, namely reading the script repeatedly, understanding the content of the script, collecting the data related to the research problem, making notes of the collected data. Then, they are classified based on the category based on the problem of the research. Furthermore, the data is interpreted and described in accordance with 
the theory adopted in this research. Finally, conclusion is drawn after fulfilling the analysis.

\section{Results and Discussion}

\subsection{Result}

This research finds that:

1. The direct race discrimination is shown as an act of limiting a job based on their race. It comes from black soldiers. There is also a tendency to discriminate between groups and beliefs with human law itself.

2. The indirect race discrimination is shown when there are some practices, policies or rules which are applied to everyone.

3. The first negative impacts of race discrimination shown in Lincoln is slavery. It is shown in the United States 13th Amendment.

4. The second impacts of race discrimination is Civil wars that causes heavy casualties between whites and blacks and took place in their territories.

\subsection{Discussion}

\subsubsection{Direct Race Discrimination}

The first direct impact of race discrimination in the movie is the act of limiting a job based on their race. The black soldiers come and talk loudly to Lincoln about what black people had to do in terms of their race to get a decent job, it seen in the following quotation:

LINCOLN
What'll you do after the war, Corporal Clark?
IRA CLARK
Work, sir. Perhaps you'll hire me.
LINCOLN
Perhaps I will.

\section{IRA CLARK}

But you should know, sir, that I get sick at the smell of bootblack and I can't cut hair. (Kushner, 2012: 6)

The above quotation shows that Ira Clark as a soldier is angry with what happens after the war. Clark does not get the job he wants because his skin color is hated by white people.

\section{FERNANDO WOOD}

We shall oppose this amendment, and any legislation that so affronts natural law, insulting to God as to man! Congrass must never declare equel those whom God Created unequal! (The Democrat cheer. Mary watches with concern. Mrs. Keckley is angry and uncomfortable).

THADDEUS STEVENS

Slavery is the only insult to natural law, you fatuous Nincompoop!

\section{GEORGE PENDLETON}

Order! Procedure! Mr. Speaker, Mr. Wood has the floor! (To STEVENS) 
Instruct us, oh Great Commoner, what is unnatural, in your opinian? Neggro casting ballots? Neggro representative? Is that natural, Stevens? Intermarrige? (Kushner, 2012: 66-67)

The quotation describes that the amendment should not be implemented in America because Fernando Wood opposed the contents of the amendment which states that all human beings is equal like white people should be equal to black people. However, there is discrimination from physical and also race. Natural law is one of the reasons why Fernando and George agree that humans should not be equated with slavery, which has been happening since their ancestors.

An event that is usually found in reality, there is a tendency to discriminate between groups and beliefs with human law itself. It is seen in the following quotation:

\section{THADDEUS STEVENS}

The true purpose of the amendment, Mr. Wood, you perfectly-named, brainless, obstructive object?

\section{FERNANDO WOOD}

You have always insisted, Mr. Stevens, that negroes are the same as white men are.

\section{THADDEUS STEVENS}

I don't hold with equality in all things only with equality before the law and nothing more.

(Surprised)

\section{FERNANDO WOOD}

That's not so! You belive that Negroes are entirely equal to white men. You've said it a thousand.

\section{THADDEUS STEVENS}

I don't hold with equality in (stands) All things, only with after the decades of fervent equality before the law and advocacy on behalf of the nothing more. Colored race.

\section{GEORGE PENDLETON}

You have long insisted, have I don't hold with equality in you not, that the dusk all things only with equality colored race is no different before the law and nothing from the white one more.

(Kushner, 2012: 139-141)

The above quotation explains that Stevens considers not to recognize equality between blacks and whites in the amendment. But in the eyes of the law that is what must be equaled in all respects without any classification with negroes. George also stresses to Stevens who is angry with him not to forget his defense that Stevens has always believed that black people were equal to white people.

\section{ROBERT}

I have to do this! And I will do it and I don't need your permission to enlist.

\section{LINCOLN}

That same speech has been made by how many sons to how many fathers since the war began?

I dont need your damn permission, you miserable old goat, I'm gonna enlist anyhow! And what wouldn't those numberless fathers have 
given to be able to say to their sons, as I now say to mine. I'm commander in chief, so in point of fact, without my permission, you ain't enlisting in nothing, nowhere, young man.

ROBERT

It's mama you're scared of, not me getting killed.

(Kushner, 2012: 150)

The quotation explains that these sons have double anxiety because apart from dealing with work problems. They are also faced with deprivation of rights that often occurs in families between children and parents. Robbert has a desire to become a soldier because he is concerned and cares about a country that is going through a civil war. Lincoln also shows concern for his son. He does not want the choice that Robert chooses will result in the loss of his life because his wife, Mary hates her husband. If Lincoln can not stop what their child wants, Robert will be killed by the decision he makes.

Direct race discrimination is seen from the scope of his own family, the right to develop oneself, without discrimination personally or collectively, to build society, nation and state.

\subsubsection{Indirect Race Discrimination}

The indirect race discrimination is seen when there's a practice, policy or rule which applies to everyone in the same way. But it has a worse effect on some people than others. It is seen in the following quotations:

\section{FERNANDO WOOD}

We are once again asked nay, command to consider a proposed thirteenth amendment which, if passed, shall set at immediate liberty four million coloreds while manacling the limbs of the white race in America. If it is passed but it shall not pass!

\section{THADDEUS STEVENS}

A point of order, Mr. Speaker, if you please? When will Mr. Wood FERNANDO WOOD

Mr. Speaker, I still have the floor and the gentleman from Pennsylvania is out of order!

\section{THADDEUS STEVENS}

When will Mr. Wood conclude his interminable gabble? Some of us breathe oxygen, and we find the mephitic fumes of his oratory a lethal challenge to our pleural capacities. (Kushner, 2012: 64)

The quotation shows that the contents of the amendment are disputed by Fernando Wood, one of the members of the democratic party who opposed the plan that had been drawn up by Lincoln. It will be indirect discrimination when a party has certain policies that harm people from racial groups. He does not approve of the policies created by Lincoln, if the amendments are implemented and passed then the government will be filled with black people who are troubling white people in America. Fernando strongly forbids and insists that the proposed 13th amendment be canceled. The debate in the conference of party groups whose contents are white people and there are no black people at all in the conference. 
In this movie script, it forbids black people from interfering with their policies and ways of working. Black people can only be slaves. Fernando Wood hated negroes so much if the contents of the amendment were passed. But it would not be passed by most white people.

\subsubsection{Negative Impacts of Race Discrimination}

The negative impacts of race discrimination found in the movie script Lincoln are slavery and civil war.

\subsubsection{Slavery}

Although some people of free color exist as well, the status of slaves usually coincides with those of Negroes creates a system and tradition in which race plays a very influential role. Slavery in the United States lasted legally until the United States 13th Amendment was adopted. It is seen in the following quotation:

(to Harold Green)

\section{LINCOLN}

How long've you been a soldier?

HAROLD GREEN

Two year, sir.

\section{LINCOLN}

Second Kansas Colored Infantry, they fought bravely at Jenkins' Ferry.

HAROLD GREEN IRA CLARK

That's right, sir. They killed a thousand rebel soldiers, sir. They were very brave.

(hesitating, then)

And making three dollars less each month than white soldiers.

HAROLD GREEN

Us 2nd Kansas boys, whenever we fight now we

IRA CLARK

Another three dollars subtracted from our pay for our uniforms.

\section{HAROLD GREEN}

That was true, yes, sir. But that changed

IRA CLARK

Equal pay now. Still no commissioned Negro officers.

(Kushner, 2012: 4)

The quotation shows that when the Negroes discusses wages in the Infantry with Lincoln, Clark and Harold receive the minimum wage compared to the whites. Discrimination at work makes them grumble about the results and positions they receive. Sometimes in these conditions their low salary are deducted for reasons of wages wearing uniforms.

\section{LINCOLN}

Two years ago I proclaimed these people emancipated, then, thenceforward and forever free. But let's say the courts deside I had no authority to do it. They might well decide that. Say there's no amendment abolishing slavery. Say it's after the war, and I can no 
longer use my war powers to just ignore the courts decisions, like I sometimes felt I had to do. Might those people I freed be ordered back into slavery? That's why I'd like to get the Thirteenth Amendment through the House, and on its way to ratification by the states, wrap the whole slavery thing up, forever and aye. As soon as I'm able. Now. End of this month. And I'd like you to stand behind me. Like my cabinet's most always done. (Kushner, 2012: 49-50)

The above quotation shows that Lincoln is angry with his cabinet members because they as white people do not support the contents of the amendments declaring freedom for black slaves. Continuous slavery still has many effects before or after the war ends. For example, the slaves were generally exploited to work as contract servants or labor in the production of crops such as tobacco and cotton.

\section{TAD}

Why do some slaves cost more than others?

ROBERT

If they're still young and healthy, if the woman can still conceive, they'll pay more.

\section{LINCOLN}

Put em back in the box. We'll return them to Mr. Gardner's studio day after next. Be careful with em, now.

(tugging at his gloves)

These things should've stayed on the calf.

TAD

(to Slade, putting the plates away)

When you were a slave, Mr. Slade, did they beat you?

WILLIAM SLADE

I was born a free man. Nobody beat me except I beat them right back. ELIZABETH KECKLEY

Mr. Lincoln, could you come with me.

$$
\text { WILLIAM SLADE }
$$

Mrs. Keckly was a slave. Ask her if she was beaten.

\section{ELIZABETH KECKLEY}

(To Ted)

I was beaten with a fire shovel when I was younger than you.

(To Lincoln)

You should go to Mrs. Lincoln. She's in Willie's room.

(Kushner, 2012: 93-94)

The quotation explains that Keckley working as a servant of Mrs. Lincoln feels the bitterness of life from childhood because of discrimination by white employers. Keckley said she was beaten with a fire shovel. It means that slavery controls the lives of others as property through coercion and restriction of movement. A person who is enslaved is not free and is forbidden to leave with white employers. Black slaves are really treated like trading commodities, like cattle and subjected to inhumane treatment. 


\subsubsection{Civil War}

Civil war as a conflict of high intensity, often involving regular armed forces, is continuous, organized conflict in great scale. Civil wars can result in heavy casualties and significant resource consumption. It is seen in the following quotations:

(he recites, fast and mechanically)

\section{SECOND WHITE SOLDIER}

Four score and seven years ago, our fathers brought forth on this continent a new nation, conceived in liberty and dedicated to the proposition that all men are created equal.

\section{LINCOLN}

That's good, thank you for

\section{FIRST WHITE SOLDIER}

Now we are engaged in a great civil war, testing whether that nation or any nation so conceived and so dedicated can long endure. We are, we are, we are met on a great battlefield of that war.

Thank you, that's.

\section{LINCOLN}

\section{SECOND WHITE SOLDIER}

We have come to dedicate a portion of that field as a final resting place for those who here gave their lives that that nation might live. It is...(He chokes up a little)

\section{FIRST WHITE SOLDIER}

His uncles, they died on the second day of fighting. (Kushner, 2012: 9)

The quotation shows that the negative impact of civil war can cause a lot of casualties between white people and black. The point is that the civil war felt by the soldiers resulted in the loss of those closest to them. White soldiers are fed up with the protracted civil war.

\section{Conclusion}

Based on the analysis of Race Discrimination in Tony Kushner's Movie Script Lincoln, some conclusions can be put forward. Race discrimination is of two kinds, namely direct race discrimination and indirect race discrimination. Race decimation always makes a difference among fellow social beings. It always gives negative impacts such as civil war and slavery, and can lead to disintegration.

\section{References}

Bogdan dan Taylor. (1975). Metodologi Penelitian Kualitatif. Bandung: Remadja Karya.

Castells, M. et al. (2011). The Power of Identity, in The Information Society and the Welfare State. doi: 10.1093/acprof:oso/9780199256990.003.0006.

Feagin, Joe. R. (1995). The Cosby Show: The View from the Black Middle Class. Florida: University of Florida.

Fulthoni, et.al,. (2009). Buku Saku Kebebasan Bergama dan Berkeyakinan (Memahami Kebijakan Administrasi Kependudukan) Jakarta: ILRC. 
Khotari. (2004). Research Methodology: Methods and Techniques. New York: Routledge.

Krout, John. A. (1971). United States to 1877. California: Routledge.

Kushner, Tony. (2012). Lincoln. https://www.amazon.com/Lincoln-Screenplay-TonyKushner/dp/155936453X.

Liliweri, Alo. (2005). Prasangka dan Konflik. Yogyakarta: LkiS Yogyakarta.

Marger, Martin N. (1994). Race and Ethnic Relations: (3nd ed). Belmont, California: Wadsworth Publishing Company.

Powel, Robert. (2006). War as a Commitment Problem. JSTOR. Vol. 60 (1). https://www.jstor.org/stable/3877871.

Quielen, Lincoln. (2006). Measuring Racial Discrimination. Contemporary Sociology: A Journal of Reviews. https://doi.org/10.1177/009430610603500165.

Reskin, Barbara F. (1998). The Proximate Causes of Employment Discrimination. In Contemporary Sociology: JSTOR. Vol. 29 (2). https://doi.org/10.2307/2654387.

Shenton, R. and Rodney, W. (1975) How Europe Underdeveloped Africa. Canadian Journal of African Studies / Revue Canadienne des Études Africaines. doi: $10.2307 / 484037$.

Sherman, Robert \& Webb, Rodman B. (1988). Qualitative Research in Education: Focus and Methods. New York: Routledge.

Soetopo, Hendyat. (2010). Perilaku Organisasi. Jakarta: PT. Remaja Rosdakarya.

Theodorsone. (1975). Sociological Theory, Its Nature and Growth. Ney York: Random House. 